
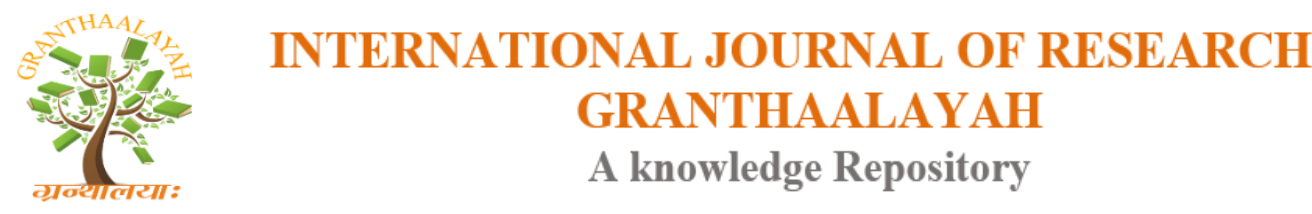

Science

\title{
EFFECT OF VARIOUS LEVELS OF METABOLIZE ENERGY ON GROWTH PERFORMANCE OF CLARIAS JAENSIS FINGERLINGS (BOULENGER, 1909)
}

\author{
Tsoupou Kuété Suzy Gwladys ${ }^{* 1}$, Efole Ewoukem Thomas ${ }^{2}$, Moussala Ottoko Junior ${ }^{2}$, \\ Tchoumboue Joseph ${ }^{2}$ \\ ${ }^{1}$ Laboratory of Aquaculture, IRAD (Institute of Agricultural Research for Development)/Limbe, \\ Cameroon \\ ${ }^{2}$ Department of Forestry and Animal Productions, Faculty of Agronomy and Agricultural \\ Sciences, University of Dschang, Cameroon
}

\begin{abstract}
The aim of this study was to contribute to the improvement of knowledge on the growth of endogenous catfish of Cameroon Clarias jaensis to develop the standards of his breeding. For this purpose, 396 fingerlings $(36.7 \pm 10.1 \mathrm{~g})$ were divided into four comparable group with three replications. Four experimental rations containing 3000, 3100, 3200 and $3300 \mathrm{Kcal} / \mathrm{kg}$ of metabolize energy were distributed in these group at $5 \%$ of ichtyobiomasse. Except the feed intake and survival rate, other growth characteristics were comparable $(\mathrm{P}>0.05)$ between rations. The higher feed intake and the lowest consumption index were recorded with the ration containing $3000 \mathrm{Kcal} / \mathrm{kg}$. The weight $(95.10 \pm 8.14 \mathrm{~g})$, total length $(23.77 \pm 1.15 \mathrm{~cm})$, weight gain $(58.70 \pm$ $9.49 \mathrm{~g})$, average daily gain $(1.01 \pm 0.16 \mathrm{~g})$, specific growth rate $(1.66 \pm 0.26 \%)$ and $\mathrm{K}$ factor $(0.71$ $\pm 0.05)$ were higher with the ration containing the lowest level of energy. This reveals that Clarias jaensis fingerlings requires less energy for growth compared to other catfish like Clarias gariepinus. In view of the above and given the cost of manufacturing the food, the ration containing $3000 \mathrm{kcal} / \mathrm{kg}$ would be agro economically sustainable although the search for the optimal level of energy remains.
\end{abstract}

Keywords: Clarias Jaensis; Energy; Growth; Fingerlings; Survival.

Cite This Article: Tsoupou Kuété Suzy Gwladys, Efole Ewoukem Thomas, Moussala Ottoko Junior, and Tchoumboue Joseph. (2018). "EFFECT OF VARIOUS LEVELS OF METABOLIZE ENERGY ON GROWTH PERFORMANCE OF CLARIAS JAENSIS FINGERLINGS (BOULENGER, 1909)." International Journal of Research - Granthaalayah, 6(5), 65-72. https://doi.org/10.29121/granthaalayah.v6.i5.2018.1427.

\section{Introduction}

Today, $31.4 \%$ of fish stocks are overexploited due to the growing demand in relation to the population explosion (FAO, 2016). Fishing alone can no longer satisfy the needs for fisheries resources in a sustainable way. Faced to this situation, aquaculture came out as a viable alternative 
which can increase fish production and avoid the destruction of natural stocks to satisfy the protein needs of the populations (Yapoga et al. 2012). Cameroon has endogenous species such as Clarias jaensis, which remains not valorized and exploited anarchically by indigenous peoples. However, their breeding could contribute to the preservation and enhancement of biodiversity and respond to consumer demand. Clarias jaensis belongs to the Clariidae family, which is a good candidate for breeding because of their hardiness, rapid growth, ability to limit the unwanted proliferation of Tilapia fry, and their highly valued meat (Micha 1974; Franc and Micha 1975; Young et al. 1996 and Ducarme et al. 2003). The development of the production of this species supposes the knowledge of its farming techniques, especially nutrition. Nutrient requirements for fish growth are multiple and all have a significant role, but energy is the most important nutrient in animal nutrition because it is the base of all cell metabolism and the use of other nutrient by the body (Sauvant, 2004). In order to better preserve and enhance Clarias jaensis, it is essential to have knowledge on its nutritional needs, especially energy. The general objective of this study is to contribute to the improvement of knowledge on the production of Clarias jaensis through the determination of its energy needs.

\section{Material and Methods}

\section{Period and Zone of the Study}

The study took place between May and July 2016 in the west region of Cameroon and at the Application and Research Farm of the University of Dschang (LN $5^{\circ} 44^{\prime}-5^{\circ} 36$ 'and $5^{\circ} 44^{\prime}-5^{\circ}$ 37 ; LE $10^{\circ} 06^{\prime}-9^{\circ} 94$ 'and $10^{\circ} 06^{\prime}-9^{\circ} 85^{\prime}$ at an altitude of $1392-1396 \mathrm{~m}$.

\section{Animal Material}

396 fingerlings with a mean weight of $36.7 \pm 10.1 \mathrm{~g}$ were fished in the natural environment of Santchou and transported in breeding pond to the study site. The fish were acclimatized for two weeks in the $1 \mathrm{~m}^{3}$ concrete tanks. During this period, they were fed ad libitum with a standard diet (3A) containing $40 \%$ of protein and consisting of wheat bran, soybean meal and fishmeal (Lacroix 2004).

\section{Experimental Diet}

Four isoproteic experimental diet (Table 1) were formulated with different energy levels 3000, 3100,3200 and $3300 \mathrm{kcal} / \mathrm{kg}$ of food. The chosen energy levels refer to those of Clarias gariepinus.

Clarias jaensis fingerlings were randomly divided into four comparable group (99 fingerlings/group) repeated 3 times with 33 fish per repetition. At each group was randomly assigned one of the experimental rations R1 (3000 kcal/kg), R2 (3100 kcal/kg), R3 (3200 kcal/kg) and R4 (3300 kcal/kg of energy). 
Table 1: Composition of expérimental diets

\begin{tabular}{|l|l|l|l|l|}
\hline Ingredients (Kg) & \multicolumn{1}{|c|}{$\begin{array}{c}\mathbf{R 1} \\
\mathbf{3 c a 0 0}\end{array}$} & $\begin{array}{c}\mathbf{R 2} \\
\mathbf{( 3 1 0 0} \\
\mathbf{k c a l} / \mathbf{k g})\end{array}$ & $\begin{array}{c}\mathbf{R 3} \\
\mathbf{( 3 2 0 0} \\
\mathbf{k c a l} / \mathbf{k g})\end{array}$ & $\begin{array}{c}\mathbf{R 4} \\
\mathbf{3 3 0 0} \\
\mathbf{k c a l} / \mathbf{k g})\end{array}$ \\
\hline Maize & 28,00 & 24,50 & 22,50 & 20,30 \\
\hline Wheat bran & 6,00 & 5,10 & 3,50 & 3,80 \\
\hline Cottonseed cake & 1,50 & 1,30 & 1,00 & 1,50 \\
\hline Soybean meal & 3,00 & 4,40 & 6,00 & 4,50 \\
\hline Fish meal & 56,70 & 57,00 & 56,50 & 57,00 \\
\hline Shell meal & 0,10 & 0,10 & 0,10 & 0,10 \\
\hline Bone meal & 0,10 & 0,10 & 0,10 & 0,10 \\
\hline Palm oil & 2,60 & 5,50 & 8,30 & 10,70 \\
\hline Premix 2\% & 2,00 & 2,00 & 2,00 & 2,00 \\
\hline Total & 100,00 & 100,00 & 100,00 & 100,00 \\
\hline Chemical composition (\%) & & & & \\
\hline CB (\%) & 40,12 & 40,45 & 40,06 & 40,00 \\
\hline ME (kcal/kg) & 3000,21 & 3102,69 & 3200,62 & 3303,65 \\
\hline Calcium (\%) & 3,80 & 3,82 & 3,65 & 3,82 \\
\hline Phosphorus (\%) & 2,12 & 2,12 & 2,07 & 2,11 \\
\hline P/E & 0,01 & 0,01 & 0,01 & 0,01 \\
\hline Ca/P & 1,80 & 1,80 & 1,80 & 1,80 \\
\hline
\end{tabular}

$\mathrm{CB}=$ Crude protein, $\mathrm{ME}=$ Metabolize energy, $\mathrm{P} / \mathrm{E}=$ Protein/energy ratio, $\mathrm{Ca} / \mathrm{P}=$ Calcium/phosphorus ratio

The trial was conducted in 12 concrete tanks of $1 \mathrm{~m}^{3}$ and covered with wire mesh. $25 \%$ of the water volume was renewed after every 3 days (Ogunjobi et al. 2012) to re-oxygenate and decrease the level of ammonia in the water. The food was served in a circular floating frame placed on the surface of the water of each tank. Below this frame was placed a bowl to collect uneaten food. The food was distributed twice a day ( 8 am and $6 \mathrm{pm}$ ) in pellet form and at $5 \%$ of the ichtyobiomasse. $20 \%$ of fish from each group were randomly taken each month, measured and weighed individually respectively by an ichtyometer and SF-400 balance $(0.1 \mathrm{~g}$ precision) to evaluate growth characteristics and adjust the amount of food to distribute. Uneaten food were collected weekly, sun-dried and weighed to estimate food consumption. The physico-chemical parameters of the water (temperature, dissolved oxygen, $\mathrm{pH}$ and conductivity) were measured weekly.

\section{Survival rate and growth characteristic}

Survival rate $(\%)$

$\mathrm{Sr}=\frac{\mathrm{Nf}}{\mathrm{Ni}} \times 100$

Nf: final number of fish, Ni: Initial number of fish;

Food Consumption $(\mathrm{g})$

$\mathrm{FC}=\mathrm{Fd}-\mathrm{Re}$

FC: food consumption, Fd: food distributed, Re: refusal

Weight gain $(\mathrm{g})$

$w g=w f-w i$

Wg: Weight gain, Wf: final average weight, Wi: initial average weight; 
Average daily gain $\left(\mathrm{g} \cdot \mathrm{d}^{-1}\right)$

$\mathrm{ADg}=\mathrm{wg} / \mathrm{T}$

ADg: Average daily gain,Wg: Weight gain (g), T: duration of the assay (day);

Specific growth rate $\left(\% . \mathrm{d}^{-1}\right)$

$\mathrm{SGR}=\frac{[\ln (\mathrm{wf})-\ln (\mathrm{wi})] \times 100}{\mathrm{~T}}$

SGR: Specific growth rate, wf: final average weight, wi: initial average weight, T: duration of the assay (day);

Consumption Index (CI)

$\mathrm{CI}=\mathrm{FC} / \mathrm{wg}$

FC: food Consumption, wg: weight gain

\section{Food cost}

Price per kilogram of food $(\mathrm{PF}): \mathrm{PF}=\Sigma(\mathrm{Xi} \times \mathrm{Px}) ; \mathrm{Xi}=$ Quantity of ingredient $\mathrm{i}$ in $(\mathrm{Kg}) ; \mathrm{Px}=$ Price of the ingredient $\mathrm{i}$ in FCFA

Price of kilogram of food consumed (PFC): PA = FC x PF; FC = Food consumption

\section{Statistical analysis}

The one-way ANOVA were used to test the effect of energy level on survival and growth characteristics. When there were significant differences between the means, they were separated by the Duncan test at 5\% significance level. SPSS 20.0 statistical software was used for these analyzes.

\section{Results}

The survival rate and growth characteristics of Clarias jaensis fingerlings are summarized in Table 2. It shows that, with the exception of food consumption and survival rate, other growth characteristics were not significantly affected by the level of energy in the diet $(\mathrm{P}>0.05)$.

Fish survival rate varied significantly $(\mathrm{P}<0.05)$ with energy level. It was lower $(70.70 \pm 1.74 \%)$ with the ration containing the most energy $(3300 \mathrm{Kcal} / \mathrm{kg})$.

The highest food consumption was obtained with the ration containing $3000 \mathrm{Kcal} / \mathrm{kg}$ of energy and lower with that containing $3100 \mathrm{Kcal} / \mathrm{kg}$.

The best consumption index was recorded with the ration containing $3000 \mathrm{Kcal} / \mathrm{kg}$ of energy although no significant difference was observed $(\mathrm{P}>0.05)$. However, this characteristic was worse with the highest energy level $(3300 \mathrm{Kcal} / \mathrm{kg})$.

Body weight were no different $(\mathrm{P}>0.05)$ between energy levels. The monthly evolution curve of weight in function of energy level (Fig 1) shows an increase in this characteristic in all treatments until the end of the test. However, fish fed the ration containing $3000 \mathrm{Kcal} / \mathrm{kg}$ had higher live weight than those fed the rations containing more energy. 
The highest weight gain and average daily gain were obtained with the diet containing 3000 $\mathrm{Kcal} / \mathrm{kg}$ of energy. Nevertheless, no significant difference $(\mathrm{P}>0.05)$ was observed between the different diets.

The greatest total length was observed at $3000 \mathrm{Kcal} / \mathrm{kg}$ of energy although there was no significant difference $(\mathrm{P}>0.05)$.

Specific growth rate did not vary significantly regardless of the energy level. In addition, it was higher with the ration containing the least energy.

The K-factor did not vary between the different diets $(\mathrm{P}>0.05)$. This factor decrease with increasing energy levels in the diet.

Table 3 shows the cost of food based on energy level. It shows that the price of the Kilogram of food increases with the energy level. The lowest cost (665.05 FCFA/kg) was obtained with the ration containing $3000 \mathrm{Kcal} / \mathrm{kg}$. On the other hand, the highest price of Kilogram of the food consumed was obtained with this same ration.

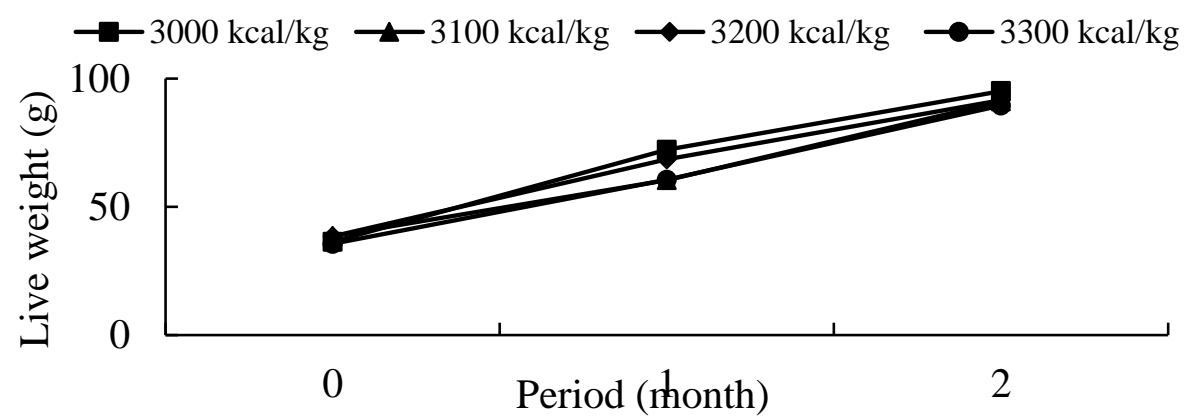

Figure 1: Monthly evolution of live weight of Clarias jaensis fingerlings in function of energy level

Table 2: Mean for growth characteristic of Clarias jaensis fingerlings in function of energy level

\begin{tabular}{|l|l|l|l|l|l|}
\hline $\begin{array}{l}\text { Growth } \\
\text { characteristics }\end{array}$ & \multicolumn{5}{|c|}{$\begin{array}{l}\text { Energy levels } \\
\text { Kcal/kg) }\end{array}$} \\
\hline & $\mathbf{3 0 0 0}$ & $\mathbf{3 1 0 0}$ & $\mathbf{3 2 0 0}$ & $\mathbf{3 3 0 0}$ & P \\
\hline SR (\%) & $94,94 \pm 8,74^{\mathrm{a}}$ & $100 \pm 0,00^{\mathrm{a}}$ & $100 \pm 0,00^{\mathrm{a}}$ & $70,70 \pm 1,74^{\mathrm{b}}$ & 0,00 \\
\hline FC (g) & $153,83 \pm 16,11^{\mathrm{a}}$ & $137,25 \pm 7,51^{\mathrm{b}}$ & $142,76 \pm 6,47^{\mathrm{b}}$ & $141,04 \pm 9,84^{\mathrm{b}}$ & 0,00 \\
\hline $\mathbf{L W}(\mathbf{g})$ & $95,10 \pm 8,14^{\mathrm{a}}$ & $91,10 \pm 6,06^{\mathrm{a}}$ & $91,60 \pm 9,57^{\mathrm{a}}$ & $89,50 \pm 8,11^{\mathrm{a}}$ & 0,30 \\
\hline TL (cm) & $23,77 \pm 1,15^{\mathrm{a}}$ & $23,45 \pm 0,79^{\mathrm{a}}$ & $23,70 \pm 0,91^{\mathrm{a}}$ & $23,68 \pm 1,18^{\mathrm{a}}$ & 0,82 \\
\hline WG (g) & $58,70 \pm 9,49^{\mathrm{a}}$ & $52,50 \pm 5,93^{\mathrm{a}}$ & $53,10 \pm 10,47^{\mathrm{a}}$ & $53,90 \pm 9,42^{\mathrm{a}}$ & 0,25 \\
\hline ADG (g) & $1,01 \pm 0,16^{\mathrm{a}}$ & $0,90 \pm 0,10^{\mathrm{a}}$ & $0,91 \pm 0,18^{\mathrm{a}}$ & $0,92 \pm 0,16^{\mathrm{a}}$ & 0,25 \\
\hline CI & $3,86 \pm 1,55^{\mathrm{a}}$ & $4,26 \pm 2,17^{\mathrm{a}}$ & $4,01 \pm 1,82^{\mathrm{a}}$ & $4,36 \pm 2,07^{\mathrm{a}}$ & 0,72 \\
\hline SGR (\%) & $1,66 \pm 0,26^{\mathrm{a}}$ & $1,48 \pm 0,20^{\mathrm{a}}$ & $1,49 \pm 0,26^{\mathrm{a}}$ & $1,59 \pm 0,27^{\mathrm{a}}$ & 0,29 \\
\hline K (\%) & $0,71 \pm 0,05^{\mathrm{a}}$ & $0,70 \pm 0,05^{\mathrm{a}}$ & $0,68 \pm 0,04^{\mathrm{a}}$ & $0,67 \pm 0,06^{\mathrm{a}}$ & 0,41 \\
\hline
\end{tabular}

$\mathrm{a}$ and $\mathrm{b}$ : the means with the same letter on the same line are not significantly different $(\mathrm{P}>0.05)$ $\mathrm{P}=$ Probability, $\mathrm{SR}=$ Survival rate $\mathrm{LW}=$ Live weight, $\mathrm{TL}=$ Total Length, $\mathrm{FC}=$ Food consumption, $\mathrm{WG}=$ Weight gain, $\mathrm{ADG}=$ Average Daily Gain, $\mathrm{CI}=$ Consumption index, $\mathrm{SGR}=$ Specific Growth Rate, $\mathrm{K}=$ Condition factor. 
Table 3: Food cost in function of energy level

\begin{tabular}{|l|l|l|l|l|l|}
\hline Ingredients & \multicolumn{5}{|c|}{ Energy levels (Kcal/kg) } \\
\hline & UP (FCFA) & $\mathbf{3 0 0 0}$ & $\mathbf{3 1 0 0}$ & $\mathbf{3 2 0 0}$ & $\mathbf{3 3 0 0}$ \\
\hline Maize & 250 & 7000 & 6125 & 5625 & 5075 \\
\hline Wheat bran & 200 & 1200 & 1020 & 700 & 760 \\
\hline Cottonseed cake & 350 & 525 & 455 & 350 & 525 \\
\hline Soybean meal & 500 & 1500 & 2200 & 3000 & 2250 \\
\hline Fish meal & 900 & 51030 & 51300 & 50850 & 51300 \\
\hline Shell meal & 150 & 15 & 15 & 15 & 15 \\
\hline Bone meal & 150 & 15 & 15 & 15 & 15 \\
\hline Palm oil & 750 & 1950 & 4125 & 6225 & 8025 \\
\hline Premix 2\% & 1500 & 3000 & 3000 & 3000 & 3000 \\
\hline Total (100 Kg) & $/$ & 66505 & 68255 & 69780 & 70965 \\
\hline PF (FCFA) & $I$ & $\mathbf{6 6 5 , 0 5}$ & $\mathbf{6 8 2 , 5 5}$ & $\mathbf{6 9 7 , 8 0}$ & $\mathbf{7 0 9 , 6 5}$ \\
\hline PFC (FCFA) & $I$ & $\mathbf{1 0 2 , 3 0}$ & $\mathbf{9 3 , 6 7}$ & $\mathbf{9 9 , 6 1}$ & $\mathbf{1 0 0 , 0 8}$ \\
\hline
\end{tabular}

$\mathrm{PF}=$ Price of $\mathrm{Kg}$ of food, $\mathrm{PFC}=$ Price of $\mathrm{Kg}$ of food consumed, $\mathrm{UP}=$ Unit price

\section{Discussion}

The survival rate of Clarias jaensis fingerlings was significantly affected by the energy level $(\mathrm{P}>0.05)$. These results are different from those of Marammazi and Khalesh (2011) who worked on fingerlings of Barbus grypus and El-Dakar et al. (2010) who reported that the survival rate of Siganus rivulatus fingerlings is not significantly affected regardless of the level of energy provided. Feed intake of pre-fattened fish was significantly $(\mathrm{P}<0.05)$ decreased with increasing energy levels. The ration containing the lowest energy level $(3000 \mathrm{Kcal} / \mathrm{kg})$ induced the highest food consumption. In addition, the lowest consumption index was obtained with this same ration, although comparable to the others $(\mathrm{P}>0.05)$. This reveals that it requires less energy for growth compared to Clarias gariepinus. These results are similar to those of Du et al. (2009) on grass carp Ctenopharyngodon idella, El-Dakar et al. (2010) on fingerlings of Siganus rivulatus and EL-Abed et al. (2013) on larvae of Decentrashus larbrax. These authors reported that food consumption declines as the consumption index increases with increasing energy levels. Note that the similarity of our results with those of El-Dakar et al. (2010) only concerns food consumption because in their study, the consumption index rather decreased with the increase of energy in the ration. The energy contained in the food is considered to be a factor that controls fish food consumption (Jobling and Wandsvik 1983; Kaushik and Luquet 1984; Kaushik and Oliva-Teles 1985; Boujard and Medale 1994 and Paspatis and Boujard 1996).

In this study, the energy level did not significantly affect $(\mathrm{P}>0.05)$ body weight, total length, weight gain, mean daily gain, specific growth rate and $\mathrm{K}$-factor. The result may be explained by a low activity of lipolytic enzymes (Von Westernhagen and Rosenthal 1976). However, these growth characteristics were better with the ration containing the least energy $(3000 \mathrm{Kcal} / \mathrm{kg})$ and lower with those containing the most energy. These results also corroborate those of Du et al. (2009), ElDakar et al. (2010) and EL-Abed et al. (2013). Indeed, Lovell (1989) demonstrated that when fish receive a food containing excess energy, its growth performance may reduce this because food consumption is low. It could be suggested that Clarias jaensis has a low ability to use dietary lipids as a source of energy, this is also observed in grass carp (Du et al. 2005; 2008 and 2009). 
The average daily gain recorded throughout the study is below the $3 \mathrm{~g} /$ day found by Lacroix (2004) during the rearing of Clarias gariepinus. The condition factor $\mathrm{K}$ values recorded throughout the test were lower 1 showing that the fish were not well. Indeed, Fulton (1902) reports that K <1 reflects a poor weight of fish and $\mathrm{K}>1$ reflects a good weight of fish.

Prices per kilogram of food increase as the energy level of the diet increases. These prices per kilogram are higher than those charged by a kilogram of the same food containing the same ingredients offered by Pouomogne, (1994). The price difference is explained by the costs of the ingredients that have blazed on the market compared to the years when the author mentioned above had conducted its study.

\section{Conclusion}

Growth characteristics were not significantly affected by energy level except for food survival and food consumption. However, the best live weight, total length, weight gain, average daily gain, consumption index, specific growth rate and $\mathrm{K}$-factor were obtained with the ration containing the least energy $(3000 \mathrm{Kcal} / \mathrm{kg})$. This ration were most economic than others.

In view of the above and given the cost of manufacturing the food, a food ration of $3000 \mathrm{kcal} / \mathrm{kg}$ would be agro economically sustainable although the search for the optimal level of energy remains.

\section{References}

[1] Boujard. T. and Medale, F. Regulation of voluntary feed intake in juvenile rainbow trout fed by hand or by self feeders with diets containing two different protein/energy ratios. Aquaculture Living Resource. 4, 1994, 211-215.

[2] Du, YZ., Tian, LX., Liang, GY. and Liu, YJ. Effect of Dietary Energy to Protein Ratios on Growth Performance and Feed Efficiency of Juvenile Grass Carp (Ctenopharyngodon idella). Open fish Science journal. 2, 2009 25-31.

[3] Du, ZY., Clouet, P., Huang, LM., Degrace, P., Zheng, WH., Tian, LX. and Liu, YJ. Utilization of different dietary lipid sources at high level in herbivorous grass carp (Ctenopharyngodon idella): mechanism related to hepatic fatty acid oxidation. Aquaculture Nutrition. 14, 2008, 77-92.

Du, ZY., Liu, YJ., Tian, LX., Wang, JT., Wang, Y. and Liang, GY. Effect of dietary lipid level on growth, feed utilization and body composition by juvenile grass carp (Ctenopharyngodon idella). Aquaculture Nutrition. 11, 2005, 179-88.

[5] Ducarne, C. and Micha, J-C. Technique de production intensive du poisson chat-poisson africain Clarias gariepinus. Tropicultura. 21 (4), 2003, 189-198.

[6] El-Dakar, A., Gaber, H., Shymaa, S., Samir, G. and Osama, Z. Survival, Growth, Feed Efficiency and Carcass Composition of Rabbitfish, Siganus Rivulatus, Fed Different Dietary Energy and Feeding Levels. Mediterranean Aquaculture Journal. 1(1), 2010, 18-27.

[7] FAO. La situation mondiale des pêches et de l'aquaculture 2016. Contribuer à la sécurité alimentaire et à la nutrition de tous. Rome. 2016, 224.

[8] Fatma, H., EL-A, Mohamed, Salama, Alaa, A. and El-Dahhar. Effect of Dietary Protein and Metabolizable Energy Levels on Growth and Feed Utilization of Sea Bass (Decentrarshus laborax) Larvae. Journal of the arabian aquaculture society. 8: (1), 2013.

[9] Franc, V. and Micha, J-C. Biologie des principales espèces utilisées en Pisciculture africaine. Symposium FAO. CIFA. SR. 8,1975, 39. 
[10] Fulton, Rate of grown of seas fishes. Science Investigatory Fisheries Division Scotland Report. 20, 1902.

[11] Jobling, M. and Wandsvik, A. An investigation of factors controlling food intake in Arctic charr, (Salvelinus alpinus L). Journal of Fish Biology. 23, 1983, 397-404.

[12] Kaushik, SJ. and de Oliva - Teles, A. Effect of digestible energy on nitrogen and energy balance in rainbow trout. Aquaculture. 50, 1985, 89-101.

[13] Kaushik, SJ. and Luquet, P. Relationship between protein intake and voluntary energy intake as affected by body weight with an estimation of maintenance needs in rainbow trout. Z. Tierphysiol. Tierernährg. u. Futtermittelkde. 51, 1984, 57-69.

[14] Lacroix, Pisciculture en zone tropicale.GFA Terra Systems Eulenkrugstraße 82 22359 Hamburg Allemagne. 231, 2004.

[15] Lovell, RT. Nutrition and feeding of fish. Van Nostrand Reinhold, New York, USA (1989)

[16] Marammazi, JG. and Kahkesh, F. Effects of dietary protein and energy levels on growth performance, feed utilization and body composition of juvenile shirbot Barbus grypus (Heckle, 1843). Iranian Journal of Fisheries Sciences. 10(3), 2011, 461-474

[17] Micha, JC. La pisciculture africaine. Espèces actuelles et nouvelles, 163-167, in Ruwet. Zoologie et association technique. Edition Fulreac, Liège. 1974, 381.

[18] Ogunjobi, AA., Owoseni, MC., Bello, OS., Ewuola, EO. and Adeleke, A. Growth performance and survival rate of Clarias gariepinus juveniles fed different levels of aflatoxin-contaminated feeds. Bulletin of Animal Health Production in Africa. 60, 2012, 519-529.

[19] Paspatis, M. and Boujard, T. A comparative study of automatic feeding and self-feeding in juvenile Atlantic salmon (Salmo salar) fed diets with different energy levels. Aquaculture. 145, 1996, 245247.

[20] Pouomogne, V. L'Alimentation du Tilapia Oreochromis niloticus en étang. Evaluation du potentiel de quelques sous-produits agro-alimentaire et modalités d'apport des aliments. Thèse de Doctorat en Halieutique de l'ENSAR, Rennes (France). 1994, 160.

[21] Sauvant, D. Principes généraux de l'alimentation animale. 2004, 147.

[22] Von, Westernhagen, H. and Rosenthal, H. Some aspects of the suitability of various Philippine siganid species (Siganidae) for mariculture. Aquaculture. 9, 1976, 297-311.

[23] Yapoga, BO., Ahou, RK., Kouamé, MK., Boua, CA. and Kouame, LP. Utilisation du soja, de la cervelle bovine et de l'asticot comme sources de protéines alimentaires chez les larves de Heterobranchus longifilis (Valenciennes, 1840). Journal of Animal and Plant Sciences. Vol.15, Issue 1, 2012, 2099-2108.

[24] Young, JA., Smith, AP. and Muir, JF. Market analysis using multiple correspondences analysis. The case of consumer acceptance of African catfish Clarias gariepinus (Burchell, 1822). Aquaculture Research, 27, 1996, 283-291.

*Corresponding author.

E-mail address: suzykut@yahoo.fr 